\title{
Eksploitasi Perempuan dalam Dwilogi Novel Kelir Slindet dan Telembuk Karya Kedung Darma Romansha
}

\author{
Novi Ermawati ${ }^{a, 1}$, Nurhadia,2 \\ ${ }^{a}$ Universitas Negeri Yogyakarta, Indonesia \\ ${ }^{1}$ novi.ermawati@studeny.uny.ac.id ; ${ }^{2}$ nurhadi@uny.ac.id
}

\section{Article info}

Article history:

Received: 19-12-2018

Revised : 13-04-2020

Accepted:20-05-2020

Keywords:

exploitation

feminist literary criticism prostitutes

women

\section{A B S T R A C T}

Not a few literary works that contain the relationship between men and women. Women are exploited from various sides. This study aims to describe: (1) the form of female exploitation, (2) the causes of female exploitation, and (3) feminist ideas in the Kelir Slindet and Telembuk novels by Kedung Darma Romansha. This research is descriptive qualitative research. Data analysis is performed by classifying data, interpreting, discussing, and summarizing data. The results of this study indicate that: first, there are seven forms of female exploitation in the Kelir Slindet and Telembuk novels, namely prostitution, child labor, forced marriage, migrant workers, sexual harassment, rape, and premarital sex. Second, four factors causing the exploitation of women in the Kelir Slindet and Telembuk novels, namely poverty, living environment, divorce, and lifestyle. Third, there are four feminist ideas as a struggle against the exploitation of women in the Kelir Slindet and Telembuk novels, namely rejecting applications, defending self-esteem, severing relationships, and leaving the work of prostitutes.

Tak sedikit karya sastra yang memuat hubungan antara laki-laki dan perempuan. Perempuan dieksploitasi dari berbagai sisi. Penelitian ini bertujuan untuk mendeskripsikan: (1) wujud eksploitasi perempuan, (2) faktor penyebab eksploitasi perempuan, dan (3) ide-ide feminis dalam dwilogi novel Kelir Slindet dan Telembuk karya Kedung Darma Romansha. Penelitian ini merupakan penelitian kualitatif deskriptif. Analisis data dilakukan dengan mengklasifikasi data, menginterpretasi, membahas, dan menyimpulkan data. Hasil penelitian ini menunjukkan bahwa: pertama, ada tujuh wujud eksploitasi perempuan dalam dwilogi novel Kelir Slindet dan Telembuk, yaitu prostitusi, pekerja anak, paksaan menikah, TKW, pelecehan seksual, perkosaan, dan hubungan seks pranikah. Kedua, faktor penyebab terjadinya eksploitasi perempuan dalam dwilogi novel Kelir Slindet dan Telembuk ada empat, yaitu kemiskinan, lingkungan tempat tinggal, perceraian, dan gaya hidup. Ketiga, ide-ide feminis sebagai perjuangan melawan ekploitasi perempuan dalam dwilogi novel Kelir Slindet dan Telembuk ada empat, yaitu menolak lamaran, membela harga diri, memutuskan hubungan, dan meninggalkan pekerjaan pelacur.

Copyright @ 2020 Institut Agama Islam Negeri Syekh Nurjati Cirebon.

\section{PENDAHULUAN}

Perempuan adalah sosok yang tak pernah luput diperbincangkan, baik dalam bidang sosial, politik (Retnani, 2017), ekonomi, agama, seni budaya sampai 
sastra. Salah satu hal yang tidak pernah habis untuk dibahas adalah mewujudkan kesetaraan dalam sistem hubungan antara laki-laki dan perempuan (Hidayati, 2018). Dalam sastra tidak jarang disebutkan bahwa perempuan sering mengalami penindasan, pelecehan, eksploitasi, dan ketidakadilan (Sugihastuti, 1998). Permasalahan-permasalahan itu memunculkan suatu gerakan yang berusaha untuk menegakkan keadilan bagi kaum perempuan yang dikenal dengan feminisme (Mulyaningsih, 2015).

Fakih (2013) menyatakan bahwa feminisme sebagai gerakan yang bermula dari asumsi bahwa kaum perempuan pada dasarnya ditindas dan dieksploitasi, serta usaha untuk mengakhiri penindasan dan eksploitasi tersebut. Salah satu penyebab munculnya gerakan ini karena adanya eksploitasi terhadap perempuan. Pengertian eksploitasi menurut Undang-Undang Republik Indonesia Nomor 21 Tahun 2007 tentang Pemberantasan Tindak Pidana Perdagangan Orang adalah tindakan dengan atau tanpa persetujuan korban, tetapi tidak terbatas pada pelacuran, kerja atau pelayanan paksa, perbudakan atau praktik serupa perbudakan, penindasan, pemerasan, pemanfaatan fisik, seksual, organ reproduksi, atau secara melawan hukum memindahkan atau mentransplantasi organ dan/atau jaringan tubuh atau memanfaatkan tenaga atau kemampuan seseorang oleh pihak lain untuk mendapatkan keuntungan baik materiil maupun immaterial.

Berdasarkan pengertian di atas jelas bahwa eksploitasi merupakan tindakan yang memanfaatkan pihak lain baik dengan persetujuan maupun tidak dengan tujuan mencari keuntungan. Eksploitasi perempuan diartikan sebagai pemanfaatan terhadap perempuan untuk memenuhi suatu kebutuhan. Kumari (2016) menyebutkan ada tiga bentuk eksploitasi perempuan, yaitu eksploitasi oleh anggota keluarga, pasangan, dan orang lain atau masyarakat. Komnas Perempuan (2017) menyatakan bahwa eksploitasi perempuan termasuk salah satu bentuk dari 15 bentuk kekerasan terhadap perempuan. Diangkatnya permasalahan eksploitasi perempuan dalam feminisme ini sebagai salah satu bukti tindakan nyata terhadap perempuan.

Eksploitasi perempuan tidak hanya terjadi di Indonesia, tetapi juga di negara-negara lain, contohnya India. Kumari (2016) memaparkan bahwa perempuan India telah dieksploitasi sejak bertahun-tahun, baik di masyarakat, wilayah, budaya, maupun agama. Perempuan menghadapi berbagai bentuk eksplotasi seperti perkosaan, penculikan, mahar, kejahatan, penganiayaan, dan pelecehan seksual. Eksploitasi perempuan dan juga anak, marak terjadi di Nepal. Khoirala \& Khadka (2018) mengemukakan bahwa Nepal saat ini menjadi negara tujuan wisata. Nepal sering digunakan untuk transit. Hal ini menyebabkan banyak tempat wisata yang menyediakan pelayanan seks anak di bawah umur. Hukum di Nepal memberi celah terhadap pedofilia yang dilakukan oleh wisatawan sehingga perdagangan manusia terutama dalam bentuk prostitusi pun juga meningkat.

Penelitian terhadap karya sastra penting dilakukan untuk mengetahui relevansi karya sastra dengan kenyataan dalam masyarakat. Dari sekian banyak karya sastra, novel merupakan bentuk karya sastra yang digemari oleh masyarakat. Novel yang digunakan peneliti adalah dwilogi novel Kelir Slindet dan Telembuk karya Kedung Darma Romansha. Dalam dwilogi novel tersebut akan sering ditemui istilah telembuk. Pertama kali membaca kata telembuk, asumsi orang akan mengarah pada dua hal. Pertama, makanan khas Indramayu yang berupa olahan tempe berbahan dasar ampas tahu. Biasanya dimasak dengan tepung terigu menjadi gorengan yang renyah atau diiris kecil-kecil dimasak orek 
dan ditambahkan leunca. Kedua, telembuk sebagai sebutan untuk pekerja seks komersial dalam bahasa Indramayu (Romansha, 2014). Pekerjaan telembuk dalam novel tersebut muncul sebagai representasi dari adanya ketidakstabilan ekonomi.

Dwilogi novel Kelir Slindet dan Telembuk sangat menarik untuk dikaji karena dalam novel ini tampak jelas adanya eksploitasi terhadap tokoh perempuan, terutama tokoh Safitri yang menjadi tokoh utama dalam kedua novel tersebut. Selain itu, ada perlawanan tokoh perempuan atas eksploitasi yang dialaminya. Teori kritik sastra feminis dianggap mampu membongkar eksploitasi yang terjadi pada tokoh perempuan, faktor penyebab, dan ide-ide feminis sebagai bentuk perlawanan terhadap eksploitasi perempuan dalam dwilogi novel Kelir Slindet dan Telembuk.

\section{METODE}

Penelitian ini merupakan penelitian kualitatif deskriptif. Adapun yang menjadi sumber data dalam penelitian ini adalah dwilogi novel karya Kedung Darma Romansha. Novel pertama berjudul Kelir Slindet yang diterbitkan pada tahun 2014 oleh PT Gramedia Pustaka Utama dengan jumlah halaman 256 (31 bab) dan novel kedua berjudul Telembuk yang diterbitkan tahun 2017 oleh Indie Book Corner dengan jumlah halaman 414 (29 bab). Teknik pengumpulan data dalam penelitian ini dilakukan dengan teknik studi pustaka untuk mencari informasi yang berbentuk tulisan dengan cara membaca karya sastra, melakukan pencatatan yang sistematis, dan melakukan analisis.

Instrumen dalam penelitian ini adalah human instrument, yaitu peneliti sendiri. Teknik analisis data yang digunakan dalam menganalisis data adalah teknik analisis deskriptif melalui kegiatan kategorisasi, tabulasi, dan inferensi. Validitas data menggunakan teknik validitas semantik, yaitu dengan cara menganalisis konteks pemaknaan terhadap teks atau naskah. Reliabilitas data dilakukan secara intrarater dengan membaca dan menganalisis data secara berulang-ulang untuk menguji konsistensi hasil pengukuran setelah data terkumpul dalam bentuk tabel data. Selain itu, realibilitas data dilakukan secara interrater dengan mendiskusikan bersama teman sejawat.

\section{HASIL DAN PEMBAHASAN Wujud Eksploitasi Perempuan Prostitusi}

Tokoh-tokoh perempuan dalam dwilogi novel Kelir Slindet dan Telembuk dieksploitasi untuk memenuhi hasrat seksual laki-laki dengan menjadi telembuk. Hal ini tergolong dalam prostitusi seperti yang dinyatakan oleh Kartono (2015) bahwa prostitusi adalah gejala kemasyarakatan, yakni wanita menjual diri melakukan perbuatan-perbuatan seksual sebagai mata pencaharian. Pada definisi tersebut jelas dinyatakan adanya peristiwa penjualan diri sebagai profesi dengan jalan melakukan relasi-relasi seksual.

Saritem, ibu dari Safitri terpaksa menjadi telembuk untuk menafkahi keluarganya karena suaminya tidak mempunyai pekerjaan tetap dan jarang memberi nafkah untuk Saritem. Bahkan, tak jarang Sukirman meminta uang kepada Saritem. Uang hasil jerih payahnya sendiri hanya dihabiskan untuk berjudi, mabuk-mabukkan, dan nelembuk. Saritem melakukan kegiatan prostitusi tersebut secara terang-terangan di rumahnya seperti kutipan berikut. 


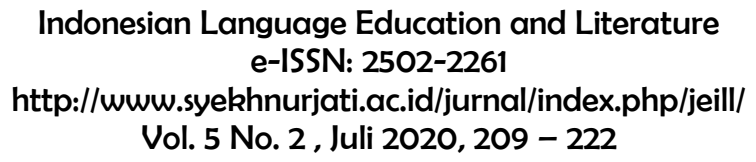

Lalu, terdengar suara derit pintu. Muncul sesosok wajah, Saritem. Tubuhnya hanya ia balut dengan jarit, mulai dari dada sampai ke lututnya. Sementara di muka pintu kamarnya terlihat seorang laki-laki tengah berdiri bertelanjang dada. Bukan Sukirman, melainkan lakilaki lain (Romansha, 2014: 135).

Dari kutipan di atas terlihat bahwa Saritem berada di kamar dengan seorang laki-laki yang bukan suaminya. Saritem melakukan kegiatan prostitusi dengan mengajak pelanggannya ke rumah. Pemandangan seperti itu kerap kali dilihat Safitri, maka tidak heran jika Safitri akhirnya juga mengikuti jejak ibunya dengan menjadi telembuk. Setelah pergi meninggalkan kampungnya, Safitri lalu menjadi telembuk kelas atas bernama Diva seperti kutipan berikut.

Dalam beberapa bulan saja, Diva sudah memiliki banyak teman dan kenalan. Dari warung ke warung, ia akan mempromosikan dirinya lewat senyuman atau matanya yang indah itu. Kemudian transaksi pun dimulai. Nego harga, lalu tancap gas. Tak terkecuali beberapa orang yang mengaku pegawai pemerintahan. Sebelum dikenalkan, para laki-laki sudah melirik Diva sejak lama. Banyak orang yang menanyakan tentang dirinya. Membicarakannya. Bahkan ada yang ingin menjadikannya istri simpanan, tapi Diva menolak (Romansha, 2017: 56).

Tokoh lain yang terjerumus dalam prostitusi adalah Mak Dayem. Mak Dayem menjadi telembuk pada usia yang masih muda dan tinggal di tempat yang berpindah-pindah sesuai pesanan seperti kutipan berikut.

"Sejak usia 20 eh... 25...ah, pokoknya sekitar itu, Mak Dayem sudah menjadi telembuk. Tempat mangkal paporit Mak Dayem di Cilege Indah. Sejak dulu tempat itu sudah ada. Konon sejak masih penjajahan Jepang. Tahun 45-an, kata orang-orang. Di situ Mak Dayem mencari uang. Dulu Mak Dayem tak punya rumah tetap, jadi rumah Mak Dayem di sembarang tempat, tergantung pesanan, hiihihii...(Romansha, 2017: 58).

Kutipan di atas menunjukkan bahwa Mak Dayem menjadi telembuk saat usianya cukup muda. Saat itu Mak Dayem sudah bercerai dengan suaminya, Catu. Mak Dayem lalu pergi ke kota untuk bekerja, susahnya mendapatkan pekerjaan, akhirnya Mak Dayem menjadi telembuk.

Wartiah dan Suti yang merupakan kakak beradik juga mengalami eksploitasi seksual dengan menjadi telembuk. Wartiah menjadi telembuk setelah bercerai dengan suaminya, sedangkan Suti menjadi pelacur karena desakan ekonomi seperti kutipan berikut.

Inilah awal malapetaka keduanya dan juga bayi mungil tak berdosa itu. Kejadian malam itu akhirnya berbuntut perceraian. Segala kepercayaan yang Wartiah pegang selama ini, telah ia lepas malam itu. Dan resminya baru ia lepas beberapa bulan kemudian. Beberapa tahun setelah perceraian itu, aku dengar Wartiah dan adiknya, Suti resmi menjadi telembuk. Menurut Kriting, desakan ekonomi yang membuatnya seperti itu - ah sekali lagi alasan yang klise. Tapi inilah 
alasan yang masuk akal dan mendapatkan rasa iba dari banyak orang (Romansha, 2017: 258).

Dari kutipan-kutipan di atas dapat disimpulkan bahwa tokoh perempuan Saritem, Diva, Mak Dayem, Wartiah, dan Suti dalam dwilogi novel Kelir Slindet dan Telembuk mengalami eksploitasi seksual untuk memenuhi hasrat seksual lakilaki dengan menjadi telembuk. Mereka terjerumus dalam prostitusi karena untuk memenuhi kebutuhan hidup.

\section{Pekerja Anak}

Ratini menjadi penyanyi dangdut tarling karena paksaan dari ayahnya. Sebelumnya Ratini selalu menolak, tetapi pada akhirnya karena tekanan ekonomi dan rasa ketertarikannya pada penampilan biduan dangdut Dede dan Aas Rolani membuatnya setuju menjadi penyanyi dangdut seperti kutipan berikut ini.

Berulang kali Ratini dipaksa menyanyi oleh orang tuanya di tempat ayahnya kerja. Awalnya Ratini menolak, lantaran kerudung yang dipakainya. Malu, katanya. Tapi, lama-lama Ratini tertarik setelah melihat penampilan Dede dan Aas Rolani di panggung. Ditambah lagi ketika Ratini banyak mendapat uang saweran, Ratini makin menikmati profesinya sebagai penyanyi dangdut tingkat kampung (Romansha, 2014: 114).

Kutipan di atas menunjukkan bahwa orang tua Ratini melakukan pemaksaan terhadap Ratini untuk menjadi penyanyi dangdut. Penghasilan ayahnya sebagai tukang kendang dirasa tidak cukup untuk memenuhi kebutuhan hidup. Saat itu, Ratini yang masih berusia 15 tahun harus menjadi penyanyi dangdut di panggung hiburan kampung seperti kutipan berikut.

Ratini, gadis 15 tahun itu terus menggoyang panggung. Senyumnya yang manja akan menarik semua laki-laki hidung belang. Sebentar lagi drama tarling akan dimulai. Sebagian orang akan mendengarkan, sebagian yang lain hanya menunggu tembang dangdut tarlingan. Selepas dangdut, suasana akan lebih sepi. (Romansha, 2014: 149).

Begitu juga Safitri yang menjadi penyanyi dangdut bersama Ratini, teman sekolahnya. Saat bernyanyi Safitri mendapat saweran yang dia gunakan untuk memenuhi kebutuhan hidup seperti kutipan berikut.

Suara gendang dan goyang maut berpadu di malam yang panas itu. Orang-orang berebut keluar masuk panggung hanya untuk bergoyang dengan safitri. Serrrrrr. Orang-orang semakin gila dibuatnya. Sekali menyawer orang-orang akan menghabiskan uang sampai dua puluh ribu. (Romansha, 2014: 190)

\section{Paksaan Menikah}

Safitri berasal dari keluarga miskin dengan orang tua Saritem, seorang pelacur dan Sukirman, buruh tani. Saat mendapat lamaran dari Ustadz Musthafa, anak Haji Nasir, tentu saja Saritem bukan main girangnya. Saritem berusaha memaksa Safitri agar menerima lamaran Ustadz Musthafa seperti kutipan berikut ini. 
Anak bodoh, kalau kamu menikah dengan Musthafa, semua beban tak ada lagi. Hidup kita makmur Fit. Emak tak perlu bercita-cita jadi TKW ke Arab Saudi lagi. Cukup di Cikedung sambil menimang cucu. Kamu lihat bapakmu itu hidupnya tidak jelas. Mengurusi diri sendiri saja tidak bisa, apalagi ngurusin keluarganya. Apa kamu mau punya suami seperti itu? Dengar, Fit, modal cinta saja tidak cukup. Karena uang akan mengubah semuanya, termasuk cinta." (Romansha, 2014: 72).

Kutipan di atas menunjukkan bahwa Safitri mendapat paksaan oleh ibunya untuk menerima lamaran Ustadz Musthafa untuk memperbaiki keadaan ekonomi keluarga. Selain itu, Ustadz Safrudin yang berasal dari kalangan berada juga melamar Safitri. Saritem berharap jika Safitri menikah dengan Safrudin, kehidupan ekonomi keluarganya akan makmur seperti kutipan berikut ini.

"Begini, Bi, sebenarnya maksud saya yang pertama ingin mempersunting Safitri. Kedua, jelas mengajaknya kembali seperti dulu, menyanyi kasidah," ujar Safrudin. Wajah Saritem berbinarbinar. Ini kesempatan emas buat anaknya.

Dendamnya pada Haji Nasir akan terbalas. Pamor keluarganya akan naik dengan cepat. Safitri tak perlu lagi menyanyi dangdut tarling, dan Saritem jelas akan berhenti total jadi telembuk. Hidupnya makmur (Romansha, 2014: 187).

Begitu pula dengan yang dialami oleh Mak Dayem. Saat itu Mak Dayem masih berusia 12 tahun. Ayah Mak Dayem seorang petani kecil yang tidak tahumenahu tentang PKI, tetapi saat terjadi penangkapan oleh tentara, ayah Mak Dayem ikut ditangkap. Tetapi, berkat Catu, ayah Mak Dayem selamat. Maka dari itu, orang tua Mak Dayem merasa berhutang budi dengan Catu dan memaksa Mak Dayem untuk menikah dengannya. Catu sendiri seorang tuan tanah yang sudah beristri seperti kutipan berikut.

"Tentu saja, goblok! Mak Dayem menikah di usia yang sangat muda. Usia 12 tahun kalau tidak salah. Mak Dayem dilamar oleh salah seorang tuan tanah." Matanya menerawang. "Mak Dayem menjadi istri mudanya. Istri simpanannya. Mak Dayem nikah siri. Usia suamiku 28 tahun lebih tua. Suami Mak Dayem memang ganteng. Meski usianya sudah 40 tahun, tapi gayanya seperti usia 20 tahun. Cangklong rokoknya panjang. Dan dia selalu murah senyum. Waktu itu Mak Dayem belum tahu apa-apa. Semua ini atas permintaan orangtuaku, dan Mak Dayem hanya menurut saja. Kamu tahu, waktu itu kami kesulitan cari makan. Untuk makan sehari saja, duh tingeling sulitnya. Di mana-mana banyak kerusuhan." (Romansha, 2017: 5960).

Kutipan di atas menunjukkan bahwa Mak Dayem menikah pada usia 12 tahun sehingga termasuk pernikahan usia dini. International Centre for Missing \& Exploited Children (2015) menyatakan bahwa salah satu faktor penyebab pernikahan dini adalah tingginya tingkat kemiskinan. Pernikahan ini diharapkan menjadi solusi bagi kesulitan ekonomi keluarga begitu pula yang terjadi dengan 
keluarga Safitri dan Mak Dayem. Hal ini senada dengan temuan Mulyaningsih \& Rostiyati (2018).

\section{Tenaga Kerja Wanita}

Berikut ini adalah kutipan yang memperlihatkan eksploitasi secara ekonomi berupa tenaga kerja wanita yang dialami oleh Istri Sidum.

"Kirik! Heh, terserah dia mau kawin lagi sama orang Arab juga tidak masalah, yang penting jatah uang nelembuk dan makan terus mengalir buatku," ujar Sidum dengan bangga. Memang setiap bulan ia mendapat jatah uang nelembuk (membayar jasa PSK), dari istrinya, dengan syarat ia tak memiliki wanita idaman lain atau menikah dengan perempuan lain (Romansha, 2014: 148-149).

Selanjutnya, kutipan yang memperlihatkan eksploitasi ekonomi yang dialami oleh Istri Casta adalah sebagai berikut.

Casta sudah mempunyai istri dan satu orang anak berumur tiga tahun. Istri Casta sekarang menjadi TKW di Malaysia. Dalam sebulan Casta mendapat jatah nelembuk empat kali atas izin istrinya. Uang buat nelembuk itu sudah dikhususkan dan tak dapat diganggu gugat. Casta dapat izin nelembuk, tapi ia mendapat larangan keras berpacaran. Boleh nelembuk, tapi tidak boleh pacaran, begitu kata Casta sewaktu kami ngobrol di jondol (Romansha, 2017: 254).

Dari dua kutipan di atas terlihat Istri Sidum dan Istri Casta dieksploitasi secara ekonomi oleh suami mereka dengan menjadi TKW untuk memenuhi kebutuhan hidup dan mereka juga memberikan uang untuk nelembuk suami mereka.

Ibu Didi juga mengalami eksploitasi secara ekonomi oleh keluarganya. Karena sudah bercerai, Ibu Didi menjadi tulang punggung keluarga. Untuk menghidupi anaknya, Ibu Didi akhirnya menjadi TKW. Apalagi waktu itu terjadi krisis ekonomi yang melanda Indonesia sehingga banyak perempuan menjadi TKW di luar negeri seperti kutipan berikut.

Mereka hanya tahu sejak krismon 1997 melanda negeri ini, banyak perempuan menjadi tulang punggung keluarga. Mereka menjadi TKW di tanah rantau. Malaysia, Brunei, Arab Saudi, dan Taiwan adalah beberapa pilihan negara tempat mereka bekerja sebagai buruh migran. Salah satunya adalah ibunya Didi. Didi yang tak pernah bengkok jalan hidupnya. Ibunya Didi harus menjadi pemimpin rumah tangga sejak cerai dengan suaminya. Membiayai sekolah Didi, sampai bisa membangun rumah di kampungnya (Romansha, 2014: 109).

\section{Pelecehan Seksual}

Profesi sebagai penyanyi dangdut dari panggung ke panggung rawan mengalami pelecehan seksual oleh penonton. Penonton memberi saweran sambil memanfaatkan tubuh penyanyi, seperti meraba-raba, mencium, meremas payudara dan pantat yang semuanya itu termasuk pelecehan seksual. Pelecehan seksual yang dialami oleh Safitri sewaktu menyanyi dangdut di panggung terlihat pada kutipan berikut ini. 
Kaji Caca mulai mengelus pinggang Safitri, lalu mengacungkan uang puluhan ribu di wajahnya. Tangannya turun, tetapi Safitri segera menarik ke pinggangnya kembali. Tangan Kaji Caca tak tinggal diam, kini ia meraba perut Safitri. Safitri menghindar, ia bergoyang agak jauh di hadapan Kaji Caca . Mata Kaji Caca meraba pinggang, lalu ke perut dan ia menghentikan pandangannya sejenak, lalu naik ke dada. Sisa uang puluhan ribu itu ia selipkan ke belahan dada Safitri yang terus bergoyang (Romansha, 2014: 192).

Dari kutipan di atas terlihat bahwa Safitri mengalami pelecehan seksual oleh Kaji Caca. Kaji Caca mengelus pinggang dan meraba perut Safitri saat Safitri sedang bernyanyi di panggung. Setelah itu, Kaji Caca memberi saweran kepada Safitri yang diselipkan ke belahan dada Safitri. Tidak hanya Safitri, ada juga tokoh lain yang mengalami pelecehan seksual karena bernyanyi di panggung. Pacar Sondak yang juga menjadi penyanyi dangdut mengalami pelecehan seksual ketika bernyanyi di panggung seperti kutipan berikut.

Goyangan penyanyi dangdut itu semakin menggila. Si penyanyi memasang bokongnya pada seorang laki-laki kurus. Laki-laki itu terus melolos uangnya sampai tandas. Ia memeluk penyanyi itu dari belakang, si penyayi terus bergoyang. Tangan si laki-laki merayap sampai ke atas, dan berhenti di payudara lalu meremasnya. "Awwww! Kirik!'” umpat penyanyi itu sambil menjauh dari laki-laki itu (Romansha, 2017: 354).

\section{Perkosaan}

Safitri, tokoh utama perempuan dalam dwilogi novel Kelir Slindet dan Telembuk mengalami peristiwa perkosaan sebanyak dua kali. Peristiwa perkosaan pertama terjadi saat malam Mapag Sri (upacara adat sebagai wujud rasa syukur kepada Tuhan atas segala nikmat yang telah diberikan kepada petani karena melimpahnya hasil panen padi di desa). Safitri diperkosa oleh orang yang tidak dikenal seperti kutipan berikut.

Ia teringat semua masa indah yang telah lewat. Saling berkejaran dengan bayang-bayang hitamnya, saling menyalip, menyusul satu sama lainnya. Dan wajah gelap laki-laki itu kembali muncul di malam keparat. Malam yang meludahi dirinya dengan birahi. Lalu ia mengusap air matanya seperti mengusap masa lalunya (Romansha, 2014: 240).

Kepergian Safitri dari Cikedung menjadi awal peristiwa perkosaan yang kedua. Saat menaiki kereta api, Safitri diperkosa oleh tiga orang laki-laki tak dikenal. Bahkan barang bawaan dan uang Safitri pun diambil seperti kutipan berikut.

Laki-laki itu berjumlah tiga orang. Mereka menggagahi Safitri secara bergiliran. Kemudian dari salah satu orang itu mencoba merebut tas Safitri dengan paksa. Sementara yang satunya lagi mengawasi dengan cemas. Takut-takut ada orang yang melihatnya, meskipun di dalam kereta barang yang gelap gulita (Romansha, 2017: 133).

Kutipan di atas menunjukkan bahwa Safitri mengalami perkosaan dalam perjalanannya saat meninggalkan Desa Cikedung. Situasi gelap di kereta membuat 
mereka leluasa untuk memperkosa Safitri. Perkosaan itu mengakibatkan benturan keras pada perutnya sehingga anak dalam kandungannya meninggal.

\section{Hubungan Seks Pranikah}

Hubungan seks pranikah merupakan salah satu bentuk eksploitasi seksual. Hal ini sesuai dengan pernyataan Komnas Perempuan (2017) bahwa tindakan mengiming-imingi perkawinan untuk memperoleh layanan seksual dari perempuan, lalu ditelantarkankan merupakan praktik eksploitasi seksual. Hubungan seks pranikah terjadi pada tokoh Wartiah. Wartiah adalah kekasih dari Kartam - teman Mukimin dari kecil. Wartiah dan Kartam yang masih berpacaran sudah melakukan hubungan seks seperti kutipan berikut.

Mereka diam sejenak. Malam belum terlalu larut benar. Wartiah semakin manja dalam dekapan Kartam. Lalu, dengan sembunyisembunyi, ia meremas payudara Wartiah, "Ah, nakal ih ..., " desis Wartiah lirih. Tak seorang pun tahu apa yang mereka lakukan di pos ronda yang sudah jadi bangkai itu (Romansha, 2017: 13).

Kutipan di atas menunjukkan bahwa Wartiah dan Kartam melakukan hubungan seks pranikah. Tindakan Kartam tersebut termasuk wujud eksploitasi seksual terhadap perempuan karena memanfaatkan kekasihnya untuk memenuhi kebutuhan seks. Hubungan seks pranikah juga dialami oleh Mak Dayem. Mak Dayem mengalami eksploitasi seksual yang dilakukan oleh kekasihnya selama beberapa tahun. Status Mak Dayem waktu itu adalah seorang janda seperti kutipan berikut ini.

"Mak Dayem melakukan hubungan seks?” potong Diva.

"Tentu saja, goblok! Aku kan sudah melakukannya dengan mantan suamiku, tentu saja tidak ada yang perlu saya khawatirkan. Toh aku juga menikmatinya. Tentu saja awalnya aku menolak ajakan pacarku itu, tapi dia terus membujukku. Akhirnya aku turuti saja. Lebih mantep dari sebelumnya." (Romansha, 2017: 73).

Nini, Sini, dan Rukminah juga mengalami eksploitasi untuk memenuhi hasrat seksual kekasih mereka, yaitu Mukimin. Mukimin merupakan anak bungsu Haji Nasir memang terkenal sebagai laki-laki yang bejat. Mukimin sebelumnya adalah seorang ustadz yang pandai berceramah, tetapi kekecewaan pada kisah cintanya di masa lalu membuat Mukimin akhirnya menjadi begundal, suka mabuk-mabukkan, main perempuan, dan berjudi. Eksploitasi seksual yang dilakukan Mukimin terhadap Nini terlihat pada kutipan berikut ini.

"Mmmhhh...A..." Perempuan itu bangkit. Berontak dari laki-laki yang baru saja menindihnya. Ia merapikan rambut dan sarung batiknya.

"Ada apa, Ni?"

"Sudah dikunci pintunya?" Tanya perempuan itu. Namanya Nini. Dan laki-laki itu Mukimin. Mukimin beranjak dari duduknya menuju ke pintu dan menggrendelnya (Romansha, 2017: 244).

Selain Nini, Mukimin mempunyai kekasih lain bernama Sini. Karena belum tuntas melampiaskan hasrat seksualnya pada Nini, Mukimin mendatangi Sini seperti kutipan berikut. 


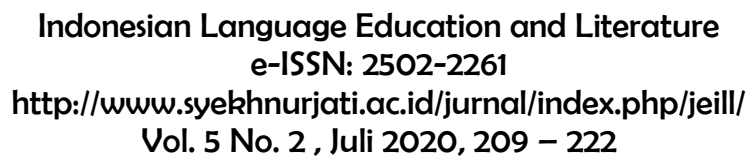

Tiba-tiba di tengah jalan ia teringat Sini. Mukimin tersenyum kecil Setidaknya ia masih ada harapan untuk mengobati kejengkelannya itu. Meskipun sekedar mengobrol tidak masalah. Setidaknya bisa melupakan adegan di ruang tamu itu. Tapi ia juga masih berharap dapat bonus lebih: dada montok Sini. (Romansha, 2017: 248).

Selain berhubungan dengan Nini dan Sini, Mukimin juga mempunyai kekasih bernama Rukminah. Selama menjadi kekasihnya, Rukminah juga dimanfaatkan oleh Mukimin untuk memenuhi hasrat seksualnya seperti kutipan berikut.

Tubuh Mukimin basah. Ia lemas lungkrah. Begitupun dengan Rukminah yang kini masih terbaring di atas rumput. Rukminah hanya memakai kaus, begitupun dengan Mukimin. Sementara bawahan mereka berdua sama-sama polos" (Romansha, 2017: 314).

Suti mengalami eksploitasi seksual oleh kekasihnya yang berasal dari kota. Keperawanan Suti diambil oleh kekasihnya dan selama bertahun-tahun menjadi pelampiasan nafsu oleh kekasihnya seperti kutipan berikut ini.

"Sakit sementara. Bentar juga ilang sakitnya," lelaki itu menerangkan. "Tapi enak kan tadi? Awalnya memang sakit, tapi kalau sudah sering, sakitnya hilang berganti nikmat," lanjutnya kemudian sambil sesekali ia menciumnya. Suti tersenyum" (Romansha, 2017: 259).

Kutipan-kutipan di atas menunjukkan bahwa perempuan-perempuan muda dimanfaatkan oleh kekasih mereka untuk memenuhi hasrat seksual. Hubungan seks pranikah tersebut dilakukan tanpa paksaan.

\section{Faktor Penyebab Eksploitasi Perempuan Kemiskinan}

Safitri menjadi telembuk karena faktor ekonomi, yaitu kemiskinan. Hal tersebut sesuai dengan apa yang diungkapkan oleh Qayyum (2013) bahwa salah satu faktor penyebab perempuan yang masuk dalam prostitusi adalah kemiskinan. Berikut adalah kutipan yang menggambarkan faktor ekonomi sebagai salah satu penyebab eksploitasi perempuan yang dialami oleh Safitri (Diva).

Beberapa bulan kemudian timbul rasa tak enak pada Mang Alek yang selama ini baik padaku. Aku ingin membalas kebaikannya. Atau sekurang-kurangnya aku dapat memenuhi kebutuhan hidupku seharihari. Setidaknya, tidak merepotkan Mang Alek. Aku seperti terdesak dengan keadaan. Tak tahu harus berbuat apa. Akhirnya aku memutuskan bekerja sebagai telembuk (Romansha, 2017: 141).

Faktor kemiskinan juga membuat Ibu Didi menjadi TKW di luar negeri untuk memenuhi kebutuhan keluarganya di kampung. Dengan menjadi TKW, Ibu Didi dapat menyekolahkan anaknya dan membangun rumah di kampung, seperti kutipan berikut ini.

Mereka hanya tahu sejak krismon 1997 melanda negeri ini, banyak perempuan menjadi tulang punggung keluarga. Mereka menjadi TKW di tanah rantau. Malaysia, Brunei, Arab Saudi, dan Taiwan adalah 
beberapa pilihan negara tempat mereka bekerja sebagai buruh migran. Salah satunya adalah ibunya Didi. Didi yang tak pernah bengkok jalan hidupnya. Ibunya Didi harus menjadi pemimpin rumah tangga sejak cerai dengan suaminya. Membiayai sekolah Didi, sampai bisa membangun rumah di kampungnya (Romansha, 2014: 109).

\section{Lingkungan Tempat Tinggal}

Lingkungan tempat tinggal Safitri, yaitu Desa Cikedung banyak didapati warung remang-remang, panggung hiburan, tempat perjudian, dan tempat pelacuran. Hal tersebut mengakibatkan mudahnya ditemui pemandangan orang yang sedang mabuk, berjudi dan bercinta seperti kutipan berikut.

Suara tawa terdengar keras dan berisik. Di seputar keramaian, seperti melihat banyak pertunjukan. Potret peristiwa yang hadir di setiap sudutnya. Orang berjudi, panggung hiburan, warung remangremang, para pedagang yang banyak ragamnya, sampai percintaan remaja di tempat-tempat gelap. Semua dapat disaksikan secara langsung (Romansha, 2014: 147).

Tentu saja lingkungan yang seperti digambarkan di atas dapat memengaruhi seseorang menjadi pelacur. Hal itulah yang terjadi dengan Safitri. Lingkungan immoral yang dilihatnya sejak kecil menyebabkan mentalnya terkondisikan dengan tindakan-tindakan asusila sehingga Safitri mudah terjerumus ke pelacuran.

\section{Perceraian}

Perceraian dialami oleh Wartiah yang menyebabkan dia mengalami eksploitasi seksual dengan menjadi pelacur. Wartiah bercerai dari suaminya, lalu terjadilah ketidakstabilan kehidupan dalam pekerjaan. Wartiah yang biasa diberi nafkah oleh suaminya, ketika menjadi single parent harus bisa memenuhi kebutuhannya sendiri. Hal itu dilakukan Wartiah dengan menjadi pelacur yang terlihat dalam kutipan berikut ini.

Inilah awal malapetaka keduanya dan juga bayi mungil tak berdosa itu. Kejadian malam itu akhirnya berbuntut perceraian. Segala kepercayaan yang Wartiah pegang selama ini, telah ia lepas malam itu. Dan resminya baru ia lepas beberapa bulan kemudian. Beberapa tahun setelah perceraian itu, aku dengar Wartiah dan adiknya, Suti resmi menjadi telembuk. Menurut Kriting, desakan ekonomi yang membuatnya seperti itu - ah sekali lagi alasan yang klise. Tapi inilah alasan yang masuk akal dan mendapatkan rasa iba dari banyak orang (Romansha, 2017: 258).

\section{Gaya Hidup}

Gaya hidup menjadi salah satu faktor penyebab eksploitasi perempuan yang dialami Suti. Suti sering pergi bersama teman-temannya di kafe-kafe, mal-mal, dan hiburan malam setelah ditinggalkan kekasihnya. Untuk memenuhi gaya hidupnya tersebut, Suti menjadi telembuk yang terlihat dalam kutipan berikut ini.

... Ia lebih banyak menghabiskan waktunya di kota. Nongkrong bersama teman-temannya di kafe-kafe, mal-mal, dan hiburan malam. Dari situ kebutuhan hidupnya bertambah, kebutuhan untuk memenuhi 
gaya hidup bersama teman-temannya. Dan dari situ pula, dari gaya hidup yang gemerlapan, ia mendapat solusinya. Maka, sejak saat itu ia tulis nasibnya menjadi telembuk, atau lebih tepat slindet (Romansha, 2017: 260-261).

\section{Ide-ide Feminis \\ Menolak Lamaran}

Menikahkan anak yang masih di bawah umur untuk memperbaiki keadaan ekonomi orang tua adalah salah satu bentuk eksploitasi secara ekonomi. Menolak lamaran merupakan salah satu usaha melawan eksploitasi. Safitri yang dilamar oleh Ustadz Musthafa, dengan keberaniannya menolak lamaran tersebut. Meskipun, Saritem terus memaksa, tetapi Safitri tetap menolaknya seperti kutipan berikut.

"Saya masih terlalu dini, Pak, untuk menikah," jawab Safitri raguragu. Sebenarnya Safitri ingin menolak secara halus. Ia tidak ingin menyinggung perasaan Musthafa" (Romansha, 2014: 94).

Dengan menolak lamaran, Safitri telah mencetuskan ide feminis untuk melawan eksploitasi. Safitri memperjuangkan kebebasan untuk memilih pasangan hidup. Feminisme memahami penindasan terhadap perempuan melalui kelompok atau kelas-kelas sosial tertentu, salah satunya dalam memilih pasangan hidup. Perempuan seharusnya berhak menikah dengan laki-laki yang dicintainya.

\section{Membela Harga Diri}

Saritem merasa direndahkan harga dirinya sebagai perempuan dan orang tua karena Haji Nasir menyuruh orang untuk mendatangi Saritem dengan tujuan melarang hubungan antara Safitri dan Mukimin. Saritem sadar akan ketidaksempurnaan dirinya karena pekerjaannya sebagai mantan telembuk, tetapi seharusnya masyarakat lebih menghargainya karena dia sudah mau berhenti dari pekerjaannya. Bentuk pembelaan harga diri dilakukan Saritem karena pada dasarnya semua manusia itu mempunyai hak yang sama untuk dihargai, meskipun itu pelacur atau mantan pelacur. Hal tersebut terlihat pada kutipan berikut.

"Jangan mentang-mentang kamu kaya, bisa seenaknya saja. Кати pikir aku tidak bisa kaya sepertimu, heh! Kirik! Biar aku miskin tapi tidak nyupang. Sudah berapa tumbal untuk kekayaanmu?! Besokbesok anakmu sendiri yang jadi korban. Setan! Dasar kaji nyupang!’" teriak Saritem dengan sejadi-jadinya.

"Ji, aku memang mantan telembuk. Apa aku tidak pantas untuk berbuat lebih baik? Aku capek dibicarakan orang-orang terus, Ji. Aku manusia. Aku masih punya harga diri. Kamu dengar kan? Saritem menangis (Romansha, 2014: 108).

\section{Memutuskan Hubungan}

Ada banyak cara memutuskan hubungan dengan pasangan, tetapi hanya sedikit sekali yang berani menghadapinya. Jika hubungan sudah tidak bisa diperbaiki, lebih baik mengakhirinya daripada terus menyakiti satu sama lain. Hal itulah yang dialami oleh Diva atau Safitri. Saat Diva tinggal bersama Mang Alek, berkali-kali Mang Alek membawa perempuan ke rumah dengan sepengetahuan 
Diva hingga pada akhirnya uang hasil Diva menjadi telembuk dan beberapa perhiasan Diva diberikan kepada seorang perempuan seperti kutipan berikut.

Dengan cepat Diva membuka kamar itu. Benar dugaannya, Mang Alek tengah berhubungan intim dengan seorang perempuan. "Bajingan...!!!! Kirik!" teriak Diva kalap. "Pantas saja uangku selalu habis, pasti karena telembuk satu ini! Kirik! Setan! Bangsat kamu!". Diva menjerit campur tangis yang berlebih. Ia lempar sepatu hak tingginya ke arah perempuan itu. Satu sepatu lolos melewati atas kepala perempuan itu, yang satunya lagi mengenai buah dada sebelah kiri perempuan itu. Plak! Satu tamparan Mang Alek mengenai pipi Diva. "dasar telembuk nyupang!" ujar Mang Alek. Diva masuk ke dalam kamarnya. Ia kemasi pakaian dan barang-barangnya dengan cepat dan pergi dari rumah itu. (Romansha, 2017: 89)

Keputusan Diva untuk meninggalkan rumah dan memutuskan hubungan dengan Mang Alek merupakan salah satu bentuk perjuangan melawan penindasan laki-laki. Dengan memutuskan hubungan Mang Alek, Diva dapat membebaskan dirinya dari eksploitasi ekonomi yang dilakukan Mang Alek. Diva dapat hidup mandiri, tanpa harus membiayai hidup Mang Alek dan Diva juga berhak menemukan laki-laki yang tulus mencintainya.

\section{Meninggalkan Pekerjaan Pelacur}

Prostitusi merupakan salah satu bentuk eksploitasi seksual yang dilakukan oleh masyarakat. Perempuan yang menjadi pelacur akan dieksploitasi untuk memenuhi hasrat seksual laki-laki. Perempuan yang terlibat dalam dunia prostitusi akan dipandang rendah oleh masyarakat. Untuk melawan eksploitasi seksual tersebut Safitri meninggalkan pekerjaannya sebagai pelacur seperti kutipan berikut ini.

"Sekarang ia hanya menjalani satu propesi saja, sebagai penyanyi organ tunggal. Katanya ia sudah menemukan laki-laki yang cocok dengannya dan dia berjanji tidak akan jadi telembuk lagi, menjadi slindet lagi setelah menikah dengannya" (Romansha, 2017: 158-159).

\section{SIMPULAN}

Berdasarkan pembahasan di atas dapat disimpulkan bahwa dalam dwilogi novel Kelir Slindet dan Telembuk ada tujuh wujud eksploitasi perempuan, yaitu prostitusi, pekerja anak, paksaan menikah, TKW, pelecehan seksual, perkosaan, dan hubungan seks pranikah. Eksploitasi perempuan yang paling dominan dialami oleh Safiri adalah prostitusi dan hubungan seks pranikah. Selanjutnya, ada empat faktor penyebab terjadinya eksploitasi, yaitu kemiskinan, lingkungan tempat tinggal, perceraian, dan gaya hidup. Faktor yang paling dominan adalah faktor kemiskinan. Terakhir, ada empat ide feminis yang diusung pengarang sebagai perjuangan melawan ekploitasi perempuan, yaitu menolak lamaran, membela harga diri, memutuskan hubungan, dan meninggalkan pekerjaan pelacur. Ide feminis yang paling dominan dan menolak adanya penindasan perempuan adalah menolak lamaran yang dilakukan oleh tokoh Safitri.

\section{DAFTAR PUSTAKA}


Fakih, M. (2013). Analisis Gender \& Transformasi Sosial. Yogyakarta: Pustaka Pelajar.

Hidayati, N. (2018). Teori Feminisme: Sejarah, Perkembangan dan Relevansinya dengan Kajian Keislaman Kontemporer. Jurnal Harkat: Media Komunikasi Gender, 14(1), 21 - 29.

International Centre for Missing \& Exploited Children. (2015). Child Marriage in The Middle East and North Africa. A publication of The Koons Family Institute on International Law \& Policy, an initiative of the International Centre for Missing \& Exploited Children. Diakses dari https://www.icmec.org/wpcontent/uploads/2015/

10/Child_Marriage_in_the_MENA_Region.pdf.

Kartono, K. (2015). Patologi Sosial Jilid 1. Jakarta: Raja Grafindo Persada.

Komnas Perempuan. (2017). Modul dan Pedoman: 15 Bentuk Kekerasan Sebuah Pengenalan. Diakses dari https://www.komnasperempuan.go.id.

Koirala, A. \& Khadka, B. R. (2018). Exploitation of Women and Children in Nepal: In The Name of Travel, Tourism and Marriage. Antyajaa: Indian Journal of Women and Social Change, 2, 155 - 159.

Kumari, J. (2016). Women Exploitation in Every Phase on Her Life and Ineffectiveness of Laws in India. International Journal of Research in Economics and Social Sciences (IJRESS), 3(9), 195 - 205.

Mulyaningsih, I. (2015). Kajian Feminis Pada Novel "Ronggeng Dukuh Paruk" dan "Perempuan Berkalung Surban". Indonesian Language Education and Literature, 1(1), $107-119$.

Mulyaningsih, I. \& Rostiyati, R. (2018). Perempuan dalam Novel Kubah Karya Ahmad Tohari. Riksa Bahasa: Jurnal Bahasa, Sastra, dan Pembelajarannya, 4(2), $181-188$.

Retnani, S. D. P. (2017). Feminisme dalam Perkembangan Aliran Pemikiran dan Hukum di Indonesia. Jurnal Ilmu Hukum: ALETHEA, l(1), 95 - 109.

Republik Indonesia. (2007). Undang-Undang Republik Indonesia Nomor 21 Tahun 2007, tentang Pemberantasan Tindak Pidana Perdagangan Orang.

Romansha, K. D. (2014). Kelir Slindet. Jakarta: Gramedia Pustaka Utama.

Romansha, K. D. (2017). Telembuk. Yogyakarta: Indie Book Corner.

Sugihastuti, S. (1998). Penelitian Kualitatif Sastra Berperspektif Feminis. Humaniora, 8, 28 - 32.

Qayyum, S., dkk. (2013). Causes and Decision of Women's Involvement into Prostitution and Its Consequences in Punjab, Pakistan. Academic Research International Journal, 4(5), 398 - 411. 